\title{
PEMENUHAN HAK ANAK ATAS DOKUMEN AKTA KELAHIRAN DI KABUPATEN NUNUKAN PROVINSI KALIMANTAN UTARA
}

\author{
Mawardi Khairi \\ Fakultas Hukum Universitas Borneo \\ Pantai Amal, Tarakan Timur \\ Kota Tarakan, Kalimantan Utara \\ Email :mawardikhairi@gmail.com \\ Inggit Akim \\ Fakultas Hukum Universitas Borneo \\ Pantai Amal, Tarakan Timur \\ Kota Tarakan, Kalimantan Utara \\ Email : akiminggit@yahoo.co.id
}

\begin{abstract}
Ownership residence documents are very important to all communities as proof of recognition by the state. The residence documents such as birth certificate is one of the rights of children that must be met by the government as a form of legal protection or recognition of citizenship. Based on the results of research shows that fulfilling the children's right to document a birth certificate in cabs Nunukan to do the service, the act of the scope of the public directly entered by local governments through measures in the form of direct services birth certificate in the office The Department of Population and Civil Registration, generally carried out (deed scope), held a collection directly children who have no birth certificates with the help of local authorities under the district, village, neighborhood / village up to the neighborhood and have signed a cooperation agreement (MOU ) to establish with competent authorities such as the Ministry of Education and Culture of Nunukan, Nunukan Nunukan hospitals and IBI Branch since 2016 as an attempt to optimize the fulfillment of the child's rights to legal documents such as birth certificate that all benefits are free. The results of this study are expected to contribute to training in specific areas of law and human rights as well as to refer both central and local governments into making future policy, especially in the area of population administration.
\end{abstract}

Key Words: rights of the child, birth certificate, policy

\section{A. PENDAHULUAN}

Berdasarkan Konvensi Hak Anak yang disetujui oleh Majelis Umum Perserikatan Bangsa - Bangsa (PBB) pada tanggal 20 November 1989 dan diratifikasi Indonesia pada tahun 1990, menyebutkan bahwa yang dimaksud dengan anak adalah setiap orang yang berusia di bawah 18 tahun. Undang - Undang Nomor 23 tahun 2002 tentang Perlindungan Anak dalam Pasal 1 juga menyebutkan bahwa anak adalah seseorang yang belum berusia 18 tahun, termasuk anak yang masih dalam kandungan. Undangundang tersebut merupakan bentuk dari hasil ratifikasi Convention On The Rights of the Child (CRC). Konvensi ini merupakan instrumen internasional di bidang hak asasi manusia dengan cakupan hak yang paling komprehensif. CRC terdiri dari 54 pasal yang hingga saat ini dikenal sebagai satusatunya konvensi di bidang Hak Asasi Manusia khususnya bagi anak - anak yang mencakup baik hak sipil dan politik maupun hak - hak ekonomi, sosial dan budaya. 
Anak dari sisi kehidupan berbangsa dan bernegara adalah masa depan bangsa dan generasi penerus cita - cita bangsa, sehingga negara berkewajiban memenuhi hak setiap anak atas kelangsungan hidup, tumbuh dan berkembang, berpartisipasi, perlindungan dari tindak kekerasan dan diskriminasi. Negara, pemerintah, masyarakat, keluarga dan orang tua berkewajiban dan bertanggung jawab terhadap penyelenggaraan perlindungan anak, karena anak dari sisi perkembangan fisik dan psikis manusia merupakan pribadi yang lemah, belum dewasa dan masih membutuhkan perlindungan. Salah satu hak anak paling vital yang wajib dipenuhi adalah masalah sipil dan kebebasan.

Dalam disiplin hukum internasional hak asasi manusia, isu hak atas identitas berbeda dengan persoalan kartu identitas (Id Card). Hak atas identitas sangat erat hubungannya dengan dokumen terkait kelahiran anak yang sifatnya wajib (compulsory) di banyak negara. Sementara sistem kartu identitas, dalam disiplin hak asasi manusia tidak diwajibkan. Hak atas identitas sangat erat kaitannya dengan hak anak mendapat pengakuan identitasnya di muka hukum. Deklarasi Universal Hak Asasi Manusia memberikan jaminan bagi setiap orang untuk mendapat pengakuan di manapun di depan hukum. Pasal 8 Konvensi Hak Anak menegaskan ketentuan negara untuk menghormati hak anak untuk memiliki identitas, termasuk kewarganegaraan, nama, dan hubungan keluarga. Dalam pasal 7 ayat (1) Keputusan Presiden Nomor 36 Tahun 1990 Tentang Pengesahan Convention On The Rights Of The Child (Konvensi Tentang Hak - Hak Anak) menyebutkan ${ }^{1}$ :

"Anak harus didaftarkan segera sesudah kelahiran dan harus mempunyai hak sejak lahir atas satu nama, hak untuk memperoleh kewarganegaraan, dan sejauh mungkin, hak hak untuk mengetahui dan dirawat oleh orang tuanya."

1 Keputusan Presiden Nomor 36 Tahun 1990 tentang Pengesahan Convention Of The Right Of TheChild (Konvensi tentang Hak-Hak Anak).
Dalam praktik, hak atas identitas anak ini berwujud dalam penerbitan akta kelahiran oleh pemerintah yang memuat paling tidak informasi dasar berupa nama anak, identitas orangtua, tanggal lahir, jenis kelamin, dan kewarganegaraan, baik berdasarkan garis keturunan (jus sanguinis/by blood) maupun berdasarkan tempat lahir (jus soli/by birth). Hampir semua pakar setuju atas pengakuan hak anak atas identitas. Situs Komisi Perlindungan Anak Indonesia pada tahun 2013 melansir informasi tidak kurang 50 juta anak di Indonesia tidak mempunyai akta kelahiran. Undang-Undang Nomor 23 Tahun 2002 jo Undang-Undang Nomor 35 Tahun 2014 tentang Perlindungan Anak telah memuat ketentuan pembuatan akta kelahiran yang memuat identitas diri setiap anak Indonesia. Dalam Undang-Undang ini, pencatatan akta kelahiran wajib dilakukan oleh penduduk paling lambat 60 (enam puluh) hari sejak kelahiran. Dengan demikian, Indonesia menerapkan stelsel aktif, yakni membebankan kewajiban melaporkan kelahiran kepada warganya. Mahkamah Konstitusi dalam perkara Nomor or/P/UNDANG - UNDANG$\mathrm{XI} / \mathrm{r} \cdot 1 \Gamma$ yang menguji stelsel aktif pencatatan akta kelahiran dalam Undang-Undang Administrasi Kependudukan menyatakan bahwa negara yang berkewajiban untuk mendaftar kelahiran anak akan tetapi karena pemerintah memiliki aparat yang sangat terbatas, dengan cakupan wilayah yang sangat luas dan dengan jumlah penduduk yang sangat banyak tidak mungkin mampu untuk mengetahui satu per satu peristiwa kelahiran yang terjadi di wilayahnya. Oleh karena itu, merupakan kewajiban bagi setiap warga negara untuk melaporkan setiap kelahiran yang terjadi. Anak dari sisi kehidupan berbangsa dan bernegara adalah masa depan bangsa dan generasi penerus cita - cita bangsa, sehingga negara berkewajiban memenuhi hak setiap anak atas kelangsungan hidup, tumbuh dan berkembang, berpartisipasi, perlindungan dari tindak kekerasan dan diskriminasi. Anak - anak yang tidak memiliki identitas rentan terhadap adanya eksploitasi. Pada umumnya 
anak - anak yang menjadi korban eksploitasi tidak memiliki catatan mengenai identitas dirinya sehingga pemalsuan jati diri anak seringkali dijadikan modus operandi oleh pelaku dalam kasus - kasus trafficking. Salah satu upaya untuk melindungi anak - anak tersebut adalah dengan memberikan akta kelahiran ${ }^{2}$. Akta kelahiran penting dimiliki karena akan dipergunakan pada saat sekolah, bukan hanya itu akta kelahiran juga memiliki fungsi sebagai kelengkapan saat melamar pekerjaan, mengurus paspor, aplikasi ijin menikah atau bercerai, menuntut hak kewarisan, dan lain-lain ${ }^{3}$.

Perlindungan terhadap anak tertuang dalam Pasal 28B ayat (2) Undang-Undang Dasar 1945 yang menyatakan4: "setiap anak berhak atas kelangsungan hidup, tumbuh dan berkembang serta berhak atas perlindungan dari kekerasan dan diskriminasi."

Pengakuan manusia sebagai subjek hukum dimulai sejak dilahirkan dan berakhir saat meninggal dunia ${ }^{5}$. Seorang anak yang masih dalam kandungan diberikan perlindungan hukum terhadap hak-hak yang akan dinikmatinya kelak. Seseorang yang tidak tercatatkan kelahirannya, tidak bisa menikmati hak-haknya sebagai subjek hukum termasuk hak untuk dilindungi negara. Pembuktian dari asal-usul anak dapat dibuktikan dengan adanya akta kelahiran otentik, yang dikeluarkan oleh pejabat yang berwenang. Lebih lanjut, sesuai dengan Undang - Undang Nomor 24 Tahun 2013 tentang Perubahan Atas Undang - Undang Nomor 23 Tahun 2006 tentang Administrasi Kependudukan sebagai dasar hukum dalam pemenuhan hak hak masyarakat atas dokumen kependudukan seperti Kartu Tanda Penduduk, Kartu

${ }^{2}$ Dewa,Akta Kelahiran Hak Masyarakat atas Identitas",http://irham1997.wordpress.com/2009/11/06/ akta kelahiran hak masyarakat atas identitas.

${ }^{3}$ United Nation.(2005). Buku Pedoman Tentang Sistem Pencatatan Sipil dan Sistem Vital Statistik Kebijakan dan Protokol Pengeluaran Catatan Pribadi dan Pencatatanya Dalam Arsip, Jakarta: P.T. Citra Grafika Pratama, hlm.6

${ }^{4}$ Indonesia, Undang-Undang Dasar Republik Indonesia Tahun 1945, Pasal 28B ayat (2)

${ }^{5}$ Salim HS.(2001). Pengantar Hukum Perdata Tertulis $(B W)$, Bandung, hlm.24.
Keluarga, Akta Kelahiran, Akta Kematian, Akta Perceraian tentu harus dipenuhi oleh pemerintah daerah selaku pelaksana teknis dalam pemenuhan dokumen kependudukan. Merujuk pada Undang-Undang Nomor 24 Tahun 2013 tentang Perubahan Atas UndangUndang Nomor 23 Tahun 2006 tentang Administrasi Kependudukan bahwa anak sebagai warga negara. Kewarganegaraan merupakan alat bukti hukum bahwa seseorang adalah warga negara yang akan terkait dengan status, perlindungan dan hak serta kewajiban anak yang bersangkutan dalam hal ini akta kelahiran. Berikut data kepemilikan dokumen kependudukan berupa akta kelahiran anak usia 0-18 Tahun Di Kabupaten Nunukan. ${ }^{6}$

\begin{tabular}{|c|c|c|c|c|c|}
\hline \multirow[t]{2}{*}{ No } & \multirow[t]{2}{*}{ Kecamatan } & \multicolumn{4}{|c|}{ Anak 0-18 Tahun } \\
\hline & & Jumlah & Memiliki & $\%$ & $\begin{array}{l}\text { Tidak Me- } \\
\text { miliki }\end{array}$ \\
\hline 1 & Sebatik & 2.099 & 1.837 & 87,52 & 262 \\
\hline 2 & Nunukan & 19.286 & 15.691 & 81,36 & 3.595 \\
\hline 3 & Sembakung & 2.239 & 1.361 & 60,79 & 878 \\
\hline 4 & Lumbis & 2.414 & 1.228 & 50,87 & 1.186 \\
\hline 5 & Krayan & 1.129 & 743 & 65,81 & 386 \\
\hline 6 & Sebuku & 3.043 & 1.372 & 45,09 & 1.671 \\
\hline 7 & $\begin{array}{l}\text { Krayan } \\
\text { Selatan }\end{array}$ & 493 & 340 & 68,97 & 153 \\
\hline 8 & Sebatik Barat & 3.466 & 2.544 & 73,40 & 922 \\
\hline 9 & $\begin{array}{l}\text { Nunukan } \\
\text { Selatan }\end{array}$ & 6.038 & 4.672 & 77,38 & 1.366 \\
\hline 10 & Sebatik Timur & 4.345 & 3.782 & 87,04 & 563 \\
\hline 11 & Sebatik Utara & 2.567 & 2.131 & 83,02 & 436 \\
\hline 12 & $\begin{array}{l}\text { Sebatik } \\
\text { Tengah }\end{array}$ & 2.613 & 1.847 & 70,69 & 766 \\
\hline 13 & Sei Menggaris & 2.890 & 1.917 & 66,33 & 973 \\
\hline 14 & Tulin Onsoi & 2.690 & 1.394 & 51,82 & 1.296 \\
\hline 15 & Lumbis Ogong & 2.011 & 1.269 & 63,10 & 742 \\
\hline 16 & $\begin{array}{l}\text { Sembakung } \\
\text { Atulai }\end{array}$ & 1.037 & 407 & 39,25 & 630 \\
\hline 17 & $\begin{array}{l}\text { Krayan } \\
\text { Tengah }\end{array}$ & 369 & 272 & 73,71 & 97 \\
\hline 18 & Krayan Timur & 475 & 336 & 70,74 & 139 \\
\hline 19 & Krayan Barat & 908 & 600 & 66,08 & 308 \\
\hline & Jumlah & 60.112 & 43.743 & 72,77 & 16.369 \\
\hline
\end{tabular}

Sumber : Data Dinas Kependudukan dan Pencatatan Sipil Kabupaten Nunukan Tahun Desember 2016

Berdasarkan data Dinas Kependudukan dan Pencatatan Sipil Kabupaten Nunukan per Desember Tahun 2016 jumlah anak usia

\footnotetext{
${ }^{6}$ Data Dinas Kependudukan dan Catatan Sipil Kabupaten Nunukan per Desember 2016
} 
0 - 18 Tahun sebanyak 60.112 anak, 43.743 anak sudah memiliki akta kelahiran dan sekitar 16.369 anak belum memiliki akta kelahiran. Kabupaten Nunukan terdiri dari 19 Kecamatan dan Kecamatan Nunukan merupakan Kecamatan yang anak usia 0-18 Tahun paling tinggi yaitu 3.595 anak belum memiliki akta kelahiran yaitu sejumlah 19.286 Anak. Berdasarkan uraian diatas maka perlu kiranya dilakukan penelitian tentang Pemenuhan Hak Anak Atas Dokumen Akta Kelahiran Di Kabupaten Nunukan Provinsi Kalimantan Utara.

Penulis merumuskan permasalahan dalam penelitian ini yaitu sebagai berikut:

1. Bagaimana bentuk kebijakan Pemerintah Daerah Kabupaten Nunukan dalam pemenuhan hak anak atas dokumen akta kelahiran?

2. Faktor - faktor / hambatan apa yang mempengaruhi tidak terlaksananya pemenuhan hak anak atas dokumen akta kelahiran?

3. Bagaimana akibat hukum terhadap anak yang tidak memiliki akta kelahiran terhadap hak-haknya sebagai Warga Negara Indonesia?

\section{B. METODE PENELITIAN}

Penelitian ini bersifat partisipatoris, yakni mengkombinasikan fungsi ganda perolehan data dan pembentukan dialog di antara pihak yang ikut ambil bagian dalam penelitian ini, bukan hanya tim peneliti pada satu pihak dan pejabat pemerintah di sisi lain, tetapi juga meliputi orang-orang dengan pengetahuan dan pengalaman yang spesifik, di wilayah kecamatan Nunukan Kabupaten Nunukan Provinsi Kalimantan Utara.

\section{PEMBAHASAN}

\section{a) Gambaran Umum Kabupaten Nunukan}

Kabupaten Nunukan merupakan satu di antara 5 Kabupaten/Kota di Provinsi Kalimantan Utara, dengan luas wilayah sebesar 14.263,68 km2. Berdasarkan letak geografis, Kabupaten Nunukan terletak di wilayah paling Utara Kalimantan yang berbatasan langsung dengan negara Malaysia, tepatnya pada posisi 3 o 30 ' 00 "'- 4o 24' 55 Lintang Utara dan 115o 22'30"-118o 44'55' Bujur Timur. Secara administratif memiliki batas-batas wilayah sebagai berikut :

a. Sebelah Utara dengan Negara Malaysia Timur-Sabah;

b. Sebelah Timur dengan Selat Makassar dan Laut Sulawesi;

c. Sebelah Selatan dengan Kabupaten Bulungan dan Kabupaten Malinau; dan

d. Sebelah Barat dengan Negara Malaysia Timur-Serawak.

Secara letak geografis Kabupaten Nunukan memilikipotensibesaruntuk mengembangkan jalinan hubungan internasional dengan dunia luar khususnya negara Malaysia, sehingga mampu mencerminkan kemajuan pembangunan diwilayah Republik Indonesia. Masyarakat Nunukan telah lama menjalin hubungan dengan Malaysia, khususnya dibidang ekonomi seperti perdagangan dan tenaga kerja. Hal tersebut sangat mempengaruhi mekanisme peredaran uang di Kabupaten Nunukan, terutama dalam transaksi perdagangan masyarakat tidak asing lagi dengan mata uang Ringgit Malaysia.

Sebagian besar wilayah Kabupaten Nunukan berbatasan langsung dengan negara Malaysia khususnya Serawak dan Sabah. Letak yang strategis ini menyebabkan Kabupaten Nunukan menjadi daerah pelintas bagi TKI yang akan bekerja di Malaysia dan Brunai Darussalam. Kondisi ini jugalah yang menyebabkan Kabupaten Nunukan secara langsung terlibat dalam pergaulan Internasional. Pada tahun 2002 Kabupaten Nunukan banyak menjadi perhatian Nasional akibat terjadinya pemulangan TKI besarbesaran dari Malaysia yang di akibatkan ketidaklengkapan dokumen keimigrasian. Sebagai Wilayah perbatasan, Kabupaten Nunukan juga menghadapi ancaman keamanan terutama kekayaan hutan, laut dan pulau-pulau perbatasan. 
Kabupaten Nunukan merupakan Kabupaten hasil pemekaran dari Kabupaten Bulungan, yang terbentuk berdasarkan pertimbangan Luas Wilayah, Peningkatan Pembangunan dan Peningkatan Pelayanan kepada Masyarakat.. Setelah ditetapkannya Undang-undang Nomor 22 Tahun 1999 tentang Pemerintahan Daerah, maka dimekarkanlah Kabupaten Bulungan menjadi 2 (dua) daerah pemekaran, yaitu Kabupaten Nunukan dan Kabupaten Malinau.Berdasarkan Undangundang tersebut maka Kabupaten Nunukan resmi menjadi Kabupaten yang terdiri dari 5 Kecamatan, yaitu Kecamatan Nunukan, Kecamatan Sebatik, Kecamatan Lumbis, Kecamatan Sembakung, dan Kecamatan Krayan. Kabupaten Nunukan adalah salah satu dari 5 kabupaten/kota di Provinsi Kalimantan Utara, Indonesia.

Berdasarkan sejarah, Kabupaten Nunukan merupakan hasil pemekaran dari Kabupaten Bulungan berdasarkan Undangundang Nomor 47 Tahun 1999, yang diubah menjadi Undang-undang Nomor 7 Tahun 2000, dengan luas wilayah 14.263,68 km2 terdiri dari 5 Kecamatan yaitu Kecamatan Nunukan, Sebatik, Lumis, Sembakung dan Krayan. Sesuai dengan tuntutan optimalisasi pelayanan publik tahun 2003 kebupaten Nunukan mekar menjadi 7 kecamatan setelah terbentuknya kecamatan Sebuku dan Krayan Selatan, tahun 2012 ada 15 kecamatan, dan hingga tahun 2015 kabupaten Nunukan terdiri dari 19 Kecamatan.

Kabupaten Nunukan sesuai data jumlah Kecamatan tahun 2017, terdapat 19 Kecamatan yang berada dalam wilayah administrasi Kabupaten Nunukan dimana 15 Kecamatan merupakan kecamatan perbatasan dengan Malaysia. Secara garis besar, tipologi kecamatan di perbatasan Kabupaten Nunukan dapat dikelompokkan menjadi tiga yaitu kecamatan yang berbatasan darat,kecamatan yang berbatasan laut, dan kecamatan yang memiliki perbatasan darat dan laut dengan Malaysia. Undang - Undang Nomor 43 tahun 2008 tentang Wilayah Negara disebutkan bahwa
"Kawasan Perbatasan adalah bagian dari Wilayah Negara yang terletak pada sisi dalam sepanjang batas wilayah Indonesia dengan negara lain, dalam hal Batas Wilayah Negara di darat, Kawasan Perbatasan berada di kecamatan". Dalam Peraturan Presiden Nomor 31 Tahun 2015 tentang Rencana Tata Ruang Wilayah Perbatasan di Kalimantan ditetapkan bahwa Kecamatan Nunukan adalah salah satu dari 12 Kecamatan perbatasan yang ada di Kabupaten Nunukan. Ada 3 (tiga) kecamatan baru yang berada dalam wilayah Krayan Kabupaten Nunukan yang belum diatur dalam Peraturan Presiden ini, mengingat Peraturan Presiden ini diterbitkan sebelum pemekaran.

Kecamatan Nunukan terletak di Pulau Nunukan, salah satu pulau yang berbatasan dengan Sabah Malaysia. Kecamatan ini memiliki luas 564,50 km2 atau 3,96\% dari total luas Kabupaten Nunukan yang tercatat sebesar 14.247,50 km2. Kecamatan Nunukan memiliki 4 (empat) kelurahan dan satu desa.Tiga kelurahan dan satu Desa terletak di pesisir pulau Nunukan, sedangkan satu kelurahan lainnya, yaitu Kelurahan Nunukan Tengah tidak memiliki batas laut. Kelurahan Nunukan Barat, Kelurahan Nunukan Utara dan Kelurahan Nunukan Timur bahkan berbatasan laut dengan Sebatik wilayah Malaysia. Jika dilihat dari posisi geografisnya, maka Kecamatan Nunukan dapat digambarkan sebagai berikut :

a. Sebelah Utara : Berbatasan dengan selat Sebatik Malaysia- Pulau Sebatik

b. Sebelah Selatan : Berbatasan dengan teluk Sebuku

c. Sebelah Barat : Berbatasan dengan selat Sebuku

d. Sebelah Timur : Berbatasan dengan Kecamatan Nunukan Selatan dan laut Sulawesi

Kabupaten Nunukan selain berbatasan dengan Sabah Malaysia juga berdekatan dengan wilayah Negara Filipina bagian selatan. Sehingga banyak warga Negara Filipina yang bekerja di Sabah Malaysia 
hingga ke pulau Sebatik Malaysia. Bahkan tidak sedikit diantara mereka kemudian berhasil memperoleh kewarganegaraan Malaysia. Dengan posisinya yang berbatasan dengan pulau Sebatik dan berdekatan dengan Tawau, salah satu kota penting di Negara bagian Sabah, Kecamatan Nunukan menjadi pintu masuk dan wilayah transit bagi masyarakat yang akan berangkat ke dan atau dari Tawau. Dengan posisinya tersebut Kecamatan Nunukan sering diperhadapkan dengan berbagai isu-isu strategis seperti keimigirasian, kejahatan transnasional, ekonomi, sosial, budaya, termasuk isu kependudukan. Salah satu isu kependudukan yang menjadi pusat perhatian Pemerintah adalah pendaftaran atau pencatatan biodata penduduk bagi WNI yang datang dari luar negeri (Malaysia).

Persoalan yang dihadapi oleh Pemerintah daerah Nunukan sebagai wilayah perbatasan adalah terkait dengan pendaftaran penduduk bagi WNI yang biasanya merupakan eks TKI yang tidak berdokumen (undocumented migrant workers) atau yang sering disebut TKI Ilegal. Dalam rangka mewujudkan tertib administrasi kependudukan dan pemenuhan atas hak sebagai warga negara, Dinas Kependudukan Dan Catatan Sipil Kabupaten Nunukan menyasar pemenuhan dokumen kependudukan di tapal batas Indonesia Malaysia sejak tahun 2017. Selain sebagai wujud pemenuhan atas hak kependudukan, layanan yang menyasar anak TKI yang menetap dan bersekolah di tapal barat Kecamatan Sebatik Tengah ini sekaligus untuk menjamin pengakuan dan penentuan status pribadi dan status hukum atas setiap peristiwa kependudukan dan peristiwa penting yang dialami anak-anak.

\section{b) Kebijakan Pemerintah Daerah Kabu- paten Nunukan Dalam Pemenuhan Hak Anak Atas Dokumen Akta Kelahiran}

Lahirnya otonomi daerah sejak tahun 1999 sebagai titik awal dari bergesernya sistem penyelenggaraan pemerintah dari sistem sentralisasi ke sistem desenteralisasi dimana pemerintah pusat menyerahkan sebagian kewenangannya kepada pemerintah daerah. Kewenangan adalah kekuasaan membuat keputusan memerintah dan melimpahkan tanggung jawab kepada orang lain . Kewenangan (authority, gezag) itu sendiri adalah kekuasaan yang diformalkan untuk orang-orang tertentu atau kekuasaan terhadap bidang pemerintahan tertentu yang berasal dari kekuasaan legislatif maupun dari pemerintah.

Kewenangan Pemerintah Daerah di atur dalam pasal 9 Undang-Undang Nomor 23 Tahun 2014 tentang Pemerintahan Daerah menyebutkan bahwa :

1. Urusan pemerintahan terdiri atas urusan pemerintahanabsolut, urusan pemerintahan konkuren, dan urusan pemerintahan umum.

2. Urusan pemerintahan absolut sebagaimana dimaksud pada ayat (1) adalah urusan Pemerintahan yang sepenuhnya menjadi kewenangan Pemerintah Pusat.

3. Urusan pemerintahan konkuren sebagaimana dimaksud pada ayat (1) adalah urusan Pemerintahan yang dibagi antara Pemerintah Pusat dan Daerah Provinsi dan Daerah Kabupaten/Kota.

4. Urusan pemerintahan konkuren yang diserahkan ke Daerah menjadi dasar pelaksanaan Otonomi Daerah.

5. Urusan pemerintahan umum sebagaimana dimaksud pada ayat (1) adalah Urusan Pemerintahan yang menjadi kewenangan Presiden sebagai kepala pemerintahan.

Selanjutnya dalam pasal 10 UndangUndang Nomor 23 Tahun 2014 tentang Pemerintahan Daerah menjelaskan mengenai urusan pemerintahan absolut, yaitu :

a. Urusan pemerintahan absolut sebagaimana dimaksud dalam Pasal 9 ayat (2) meliputi:

a. politik luar negeri;

b. pertahanan;

c. keamanan;

d. yustisi;

e. moneter dan fiskal nasional; dan

f. agama. 
b. Dalam menyelenggarakan urusan pemerintahan absolut sebagaimana dimaksud pada ayat (1), Pemerintah Pusat:

a. Melaksanakan sendiri; atau

b. Melimpahkan wewenang kepada instansi vertikal yang ada di daerah atau gubernur sebagai wakil pemerintahpusat berdasarkan asas dekonsentrasi.

Kemudian dijelaskan dalam Pasal 11 Undang-Undang Nomor 23 Tahun 2014 tentang Pemerintahan Daerah mengenai urusan pemerintahan konkuren, yaitu :

1) Urusan pemerintahan konkuren sebagaimana dimaksud dalam Pasal 9 ayat (3)yangmenjadikewenanganDaerahterdiri atasUrusanPemerintahan WajibdanUrusan Pemerintahan Pilihan.

2) Urusan Pemerintahan Wajib sebagaimana dimaksud pada ayat (1) terdiri atas Urusan Pemerintahan yang berkaitan dengan Pelayanan Dasar dan Urusan Pemerintahan yang tidak berkaitan dengan Pelayanan Dasar.

3) Urusan Pemerintahan Wajib yang berkaitan dengan Pelayanan Dasar sebagaimana dimaksud pada ayat (2) adalah Urusan Pemerintahan Wajib yang sebagian substansinya merupakan Pelayanan Dasar.

Dalam Pasal 12 Undang-Undang Nomor

23 Tahun 2014 tentang Pemerintahan Daerah menjelaskan bahwa :

1) Urusan Pemerintahan Wajib yang berkaitan dengan Pelayanan Dasar sebagaimana dimaksud dalam Pasal 11 ayat (2) meliputi: a. pendidikan;

b. kesehatan;

c. pekerjaan umum dan penataan ruang;

d. perumahan rakyat dan kawasan permukiman;

e. ketenteraman, ketertiban umum, dan pelindungan masyarakat; dan

f. sosial.

2) Urusan Pemerintahan Wajib yang tidak berkaitan dengan Pelayanan Dasar sebagaimana dimaksud dalam Pasal 11 ayat

(2) meliputi:

a. tenaga kerja; b. pemberdayaan perempuan dan pelindungan anak;

c. pangan;

d. pertanahan;

e. lingkungan hidup;

f. administrasi kependudukan dan pencatatan sipil;

g. pemberdayaan masyarakat dan Desa;

h. pengendalian penduduk dan keluarga berencana;

i. perhubungan;

j. komunikasi dan informatika;

k. koperasi, usaha kecil, dan menengah;

1. penanaman modal;

m. kepemudaan dan olah raga;

n. statistik;

o. persandian;

p. kebudayaan;

q. perpustakaan; dan

r. kearsipan.

3) Urusan Pemerintahan Pilihan sebagaimana dimaksud dalam Pasal 11 ayat (1) meliputi:

a. kelautan dan perikanan;

b. pariwisata;

c. pertanian;

d. kehutanan;

e. energi dan sumber daya mineral;

f. perdagangan;

g. perindustrian dan transmigrasi

Berdasarkan ketentuan pasal 12 ayat 2 huruf f Undang -Undang Nomor 23 Tahun 2014 tentang Pemerintahan Daerah bahwa kewenangan pemerintah daerah dalam hal kependudukan dan pencatatnan sipil termasuk urusan pemerintahan wajib yang tidak berkaitan dengan pelayanan dasar. Pemerintah Kabupaten Nunukan sebagai salah satu daerah otonom dalam penyelenggaraan urusan kependudukan dan pencatatan sipil telah memberikan tugas kepada Dinas Kependudukan dan Pencatatan Sipil untuk memberikan pelayanan terhadap pemenuhan dokumen kependudukan khususnya dalam pemenuhan hak anak atas akta kelahiran.

Akta kelahiran adalah bukti sah mengenai status dan peristiwa kelahiran seseorang yang dikeluarkan oleh Dinas Kependudukan dan Pencatatan Sipil. Bayi 
yang dilaporkan kelahirannya akan terdaftar dalam kartu keluarga dan diberi nomor induk kependudukan (NIK) sebagai dasar untuk memperoleh pelayanan masyarakat lainnya. Adapun manfaat akta kelahiran sebagai berikut:

1. Identitas anak

2. Administrasi kependudukan : KTP, KK

3. Untuk keperluan sekolah

4. Untuk pendaftaran pernikahan di KUA

5. Mendaftar pekerjaan

6. Persyaratan pembuatan paspor

7. Untuk mengurus hak ahli waris

8. Mengurus asuransi

9. Mengurus tunjangan keluarga

10. Mengurus hak dana pensiun

11. Untuk melaksanakan ibadah haji

Syarat-syarat yang harus dipenuhi dalam permohonan pembuatan akta kelahiran baru sebagai berikut:

1. Foto copy akta nikah (bagi orang tua yang sudah bercerai dengan menggunakan Akta Cerai) yang telah dilegalisir KUA *apabila tidak bisa memberikan Surat Akta Nikah atau Itsbat maka Anak Merupakan Anak Ibu

2. Untuk anak yang tidak diketahui asal usulnya persyaratan pembuatan akta harus dilengkapi dengan Surat Keterangan dari Kepolisian(menjelaskanasalusulanak)dan dokter (menjelaskan perkiraan usia anak)

3. Foto copy Kartu Keluarga yang dilegalisir

4. Foto copy KTPAyah dan Ibu, jika usia diatas 17 tahun menggunakan KTP Sendiri

5. 2 Orang Saksi Pencatatan Pelaporan Kelahiran berikutfotocopyKTPyangMasih Berlaku

6. Surat Keterangan Lahir dari Kepala Desa / Lurah, Dokter, Bidan, Rumah Sakit yang disahkan di desa / kelurahan

7. Surat Kuasa Bermaterai Rp 6.000,- apabila pencatatan dikuasakan

8. Mengisi Formulir Permohonan Pencatatan Kelahiran bermaterai Rp 6.000,-

Dalam rangka melakukan pemenuhan hak anak atas akta kelahiran Dinas Kependudukan dan Pencatatan Sipil telah menempuh berbagai kebijakan antara lain sebagai berikut:

1. Melakukan Penandatanganan Mou Ker- jasama Dengan Organ Pemerintah Daerah (OPD)

Pemenuhan hak anak atas dokumen akta kelahiran merupakan salah satu hak dasar yang harus diberikan kepada anak. Berdasarkan hasil wawancara dengan Kepala Dinas Kependudukan Dan Pencatatan Sipil Kabupaten Nunukan bahwa dalam rangka pemenuhan dokumen akta kelahiran bagi anak usia 0-18 tahun telah dilakukan penandatanganan kerjasa sama dengan Rumah Sakit Umum Daerah Kabupaten Nunukan,Ikatan Bidan Indonesia Cabang Kabupaten Nunukan dan Dinas Pendidikan Dan Kebudayaan Kabupaten Nunukan, kerjasama ini di tuangkan dalam bentuk MOU.

Perjanjian Kerjasama Dinas Kependudukan dan Pencatatan Sipil dengan Rumah Sakit Umum Daerah Kabupaten Nunukan tertuang pada MOU nomor 472. II/BII.2/159/DKPS/VII/2016 dan Nomor 046/PKS/RSUD-NNK/VII/2016 tanggal 18 Juli Tahun 2016 dengan ruang lingkup perjanjian adalaj pelayanan Akta kelahiran yang meliputi pelaksanaan penerimaan dan pemrosesan berkas permohonan penerbitan Akta kelahiran yang peristiwa kelahirannya antara 0 (nol) sampai dengan 60 (enam puluh) hari. Adapun maksud tujuan dan sasarannya adalah sebagai berikut :

a. Mewujudkanterciptanyakerjasamasinergis antara para pihak yang berkaitan dengan pelayanan prima penerbitan kutipan Akta kelahirandanmeningkatkan citra pelayanan kepada masyarakat.

b. Meningkatkan pelayanan masyarakat bagi pemohon Akta kelahiran yang persitiwanya terjadi di RSUD Nunukan

c. Memberikan kepastian status hokum pada anak atas kepemilikan Akta kelahiran

d. Menciptakan sinergi yang harmonis,serasi dan terpadu dalam pelaksanaan tugas antara para pihak agar tercapai hasil guna dan daya guna.

Selanjutnya berdasarkan wawancara dengan Daningtyas Rhina Pawitri,Amd,Keb menjelaskan bahwa bagi masyarakat yang 
proses kelahirannya dibantu oleh bidan yang memiliki izin praktek maka di terbitkan surat keterangan lahir yang kemudian data tersebut di kirimkan oleh bidan ke petugas Dinas Kependudukan dan Pencatatan Sipill melalui aplikasi Telegram/ Whatsaap Group untuk mempercepat pembuatan Akta kelahiran sehingga pembuatan Akta kelahiran yang memiliki surat keterangan lahir melalui proses reguler /layanan khusus sedangkan bagi anak yang tidak memiliki surat keterangan lahir orang tua anak bersangkutan mengurus langsung pembuatan Akta kelahiran ke Dinas Kependudukan dan Pencatatan Sipill. Pihak IBI tidak berani menerbitkan surat keterangan lahir bagi anak yang kelahirannya tidak dbantu oleh bidan resmi sebagai langkah antisipasi masalah hukum di kemudian hari khususnya tentang status anak bersangkutan. Hal ini juga berdasarkan isi perjanjian kerjasama pihak IBI Cabang Kabupaten Nunukan dengan Dinas Kependudukan dan Pencatatan Sipil dengan Nomor 147-Dinas Kependudukan dan Pencatatan Sipil/472. II/B.II.2/IV/2017,Nomor 10/PC-IBI/NNK/ IV/2017 pada tanggal 3 April 2017.

Disampingituberdasarkanhasilwawancara dengan dr.Ika Bihandayani bagi masyarakat yang proses kelahirannya di Puskesmas Nunukan maka puskesmas menerbitkan surat keterangan lahir yang kemudian data tersebut dikirimkan oleh puskesmas ke Dinas Kependudukan dan Pencatatan Sipill melalui aplikasi telegram atau Whatsaap group untuk mempercepat pembuatan Akta kelahiran sehingga pembuatan Akta kelahiran yang memiliki surat keterangan lahir melalui proses reguler/layanan khusus sedangkan bagi anak yang tidak memiliki surat keterangan lahir, orang tua anak bersangkutan mengurus secara langsung pembuatan Akta kelahiran ke Dinas Kependudukan dan Pencatatan Sipill. Pihak Puskesmas tidak berani menerbitkan surat keterangan lahir bagi anak yang kelahirannya tidak dbantu oleh Bidan Puskesmas sebagai langkah antisipasi masalah hukum di kemudian hari khususnya tentang status anak bersangkutan.
Demikian juga menurut Bapak Abdul Azis menerangkan bahwa Dinas Pendidikan Dan Kebudayaan Kabupaten Nunukan telah mempersyaratkan anak usia sekolah/yang masuk sekolah mulai dari PAUD,SD dan SMP wajib melampirkan Akta kelahiran sebagai dasar penyusunan daptar pokok pendidikan untuk penerbitan nomor induk siswa hal ini dalam rangka pengisian raport dan penerbitan ijazah benar-benar sudah sesuai dengan Akta kelahiran.Bagi anak yang belum memiliki Akta kelahiran tetap di berikan hak untuk sekolah dengan syarat anak/wali murid tersebut harus mengurus Akta kelahiran anak ke Disdukcapi dengan di fasilitasi oleh pihak sekolah bersangkutan secara kolektif dengan melengkapi syarat-syarat yang telah di tentukan. Ketentuan ini berdasarkan Perjanjian Kerjasama Dinas Pendidikan Dan Kebudayaan dengan Dinas Kependudukan dan Pencatatan Sipil Nomor:146-Dinas Kependudukan dan Pencatatan Sipil/472.II/B. II.2/IV/2017 dan Nomor:304-Disdikbud/197/ II/IV/2017 pada tanggal 3 April 2017.

\section{Pelayanan Langsung Di Kantor Dinas Kependudukan Dan Pencatatan Sipil}

Bahwa dalam rangka pemenuhan akta kelahiran bagi anak usia 0-18 tahun dinas kependudukan dan catatan sipil kabupaten nunukan Selain dalam bentuk kerjasama pembuatan akta kelahiran juga dapat secara langsung dilakukan di kantor dinas selama hari kerja dengan SOP sebagai berikut:

1. Pemohonmenyerahkanberkaskelengkapan penerbitan akta kelahiran.

2. Petugas loket Dinas Kependudukan dan Pencatatan Sipil menerima berkas,memferipikasi kelengkapan berkas dan mencatat data pemohon kedalam buku pendaptaran (apabila berkas lengkap akan diterima oleh petugas Dinas Kependudukan dan Pencatatan Sipil,apabila berkas belum lengkap akan di kembalikan kepada pemohon)

3. Kasi pendaptaran penduduk memberikan nomor induk kependudukan

4. Operator mengentry data ke dalam SIAK 
5. Kasi kelahiran dan kematian dan Kabid Pencatatatan Sipil memverifikasi dan memaraf draft akta kelahiran

6. Operator meregister dan mencetak kutipan akta kelahiran

7. Kepala Dinas Kependudukan dan Pencatatan Sipil menandatangani kutipan akta kelahiran yang telah tercetak

8. Kutipan akta kelahiran di serahkan ke petugas loket untuk di serahkan kepada pemohon.

Standar Operasional Prosedur dapat di gambarkan sebagai berikut:

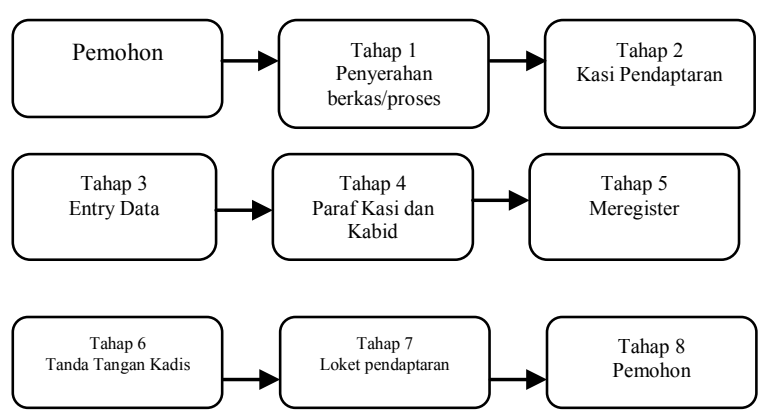

Syarat-syarat yang harus dipenuhi dalam Permohonan pembuatan akta kelahiran baru sebagai berikut: ${ }^{7}$

1. Foto copy akta nikah (bagi orang tua yang sudah bercerai dengan menggunakan akta cerai) yang telah dilegalisir kua *apabila tidak bisa memberikan surat akta nikah atau itsbat maka anak merupakan anak ibu

2. Untuk anak yang tidak diketahui asal usulnya persyaratan pembuatan akta harus dilengkapi dengan surat keterangan dari kepolisian (menjelaskan asal usul anak) dan dokter (menjelaskan perkiraan usia anak)

3. Foto copy kartu keluarga yang dilegalisir

4. Foto copy ktp ayah dan ibu, jika usia diatas 17 tahun menggunakan ktp sendiri

5. 2 orang saksi catatan pelaporan kelahiran berikut foto copy ktp yang masih berlaku

6. Suratketeranganlahirdarikepaladesa/lurah, dokter, bidan, rumah sakit yang disahkan di desa / kelurahan

7. Surat kuasa bermaterai rp 6.000,- apabila catatan dikuasakan

$$
{ }^{7} \text { Ibid. }
$$

8. Mengisi formulir permohonan catatan kelahiran bermaterai Rp 6.000,-

\section{Melakukan Pelayanan Keliling (Akta Keliling)}

Bahwa dalam rangka pemenuhan Akta kelahiran bagi anak usia 0-18 tahun dinas kependudukan dan catatan sipil kabupaten nunukan Karena kondisi geografis kabupaten nunukan yang luas maka Dinas Kependudukan dan Pencatatan Sipill membagai zona pelayanan pembuatan dokumen kependudukan khususnya Akta kelahiran sebagai berikut:

a) Zona Satu (Zona Merah) meliputi Kecamatan Krayan Tengah,Krayan Timur,Krayan Barat,Krayan Selatan,Krayan dan Lumbis Ogong.

b) Zona Dua (Zona Kuning) meliputi Kecamatan Sembakung, Lumbis, Sebuku, Sei Menggaris, Tulin Onsoi dan Sembakung Atulai

c) ZonaTiga(ZonaHijau)meliputiKecamatan Sebatik,Nunukan,Sebatik Barat,Nunukan Selatan,Sebatik Timur,Sebatik Tengah dan Sebatik Utara,).

Sebelum mendatangi zona-zona tersebut pihak Dinas Kependudukan dan Pencatatan Sipill berkoordinasi dengan Kecamatan dan atau Kelurahan untuk terlebih dahulu mensosialisasikan kepada masyarakat tentang adanya layanan pembuatan/perbaikan data kependukan di daerah tersebut sehingga masyarakat di minta untuk hadir untuk melakukan pembuatan/perbaikan data pada hari dan waktu yang telah di tetapkan yang selanjutnya di terbitkan langsung pada saat perbaikan /pembuatan dokumen tersebut di tempat dan apabila tidak bisa di tempat maka berkas akan dibawa ke kantor dinas yang selanjutnya apabila sudah jadi akan di kirimkan ke Kelurahan domisil masyarakat bersangkutan lalu di distribusikan.

\section{Pendataan Melalui Lingkungan Hingga Rukun Tetangga}

Disamping ketiga bentuk kebijakan yang telah di tempuh oleh Dinas Kependudukan dan 
Pencatatan Sipil Kabupaten Nunukan,juga telah melakukan koordinasi melalui Kecamatan,Kelurahan,Lingkungan hingga Rukum Tetangga untuk melakukan pendataan anak yang belum memiliki dokumen kependudukan berupa Akta kelahiran.

Berdasarkan kebijakan-kebijakan yang telah di uraikan dapat kita lihat sejauhmana capaian dalam pemenuhan hak anak atas dokumen kependudukan berupa Akta kelahiran kurun waktu tahun 2016-2018 antara lain sebagai berikut:

\begin{tabular}{|c|c|c|c|c|c|}
\hline \multirow[t]{2}{*}{ No } & \multirow[t]{2}{*}{ Kecamatan } & \multicolumn{4}{|c|}{ Anak 0-18 TAHUN } \\
\hline & & $\begin{array}{c}\text { Jumlah } \\
\text { Anak }\end{array}$ & $\begin{array}{l}\text { Memi- } \\
\text { liki }\end{array}$ & $\%$ & $\begin{array}{c}\text { Tidak } \\
\text { Memiliki }\end{array}$ \\
\hline 1 & Sebatik & 2.306 & 1.839 & 79,75 & 467 \\
\hline 2 & Nunukan & 20.150 & 15.747 & 78,15 & 4403 \\
\hline 3 & Sembakung & 2.178 & 1.362 & 62,53 & 816 \\
\hline 4 & Lumbis & 2.400 & 1.237 & 51,54 & 1163 \\
\hline 5 & Krayan & 1.087 & 744 & 68,45 & 343 \\
\hline 6 & Sebuku & 3.264 & 1.383 & 42,37 & 1881 \\
\hline 7 & Krayan Selatan & 485 & 342 & 70,52 & 143 \\
\hline 8 & Sebatik Barat & 3.533 & 2.560 & 72,46 & 973 \\
\hline 9 & Nunukan Selatan & 6.187 & 4.675 & 75,76 & 1512 \\
\hline 10 & Sebatik Timur & 4.569 & 3.800 & 83,17 & 769 \\
\hline 11 & Sebatik Utara & 2.724 & 2.141 & 78,60 & 583 \\
\hline 12 & Sebatik Tengah & 2.611 & 1.874 & 71,77 & 737 \\
\hline 13 & Sei Menggaris & 2.265 & 1.922 & 58,87 & 1343 \\
\hline 14 & Tulin Onsoi & 2.835 & 1.400 & 49,38 & 1435 \\
\hline 15 & Lumbis Ogong & 2.183 & 1.270 & 58,18 & 913 \\
\hline 16 & Sembakung Atulai & 975 & 408 & 41,85 & 567 \\
\hline 17 & Krayan Tengah & 403 & 272 & 67,49 & 131 \\
\hline 18 & Krayan Timur & 464 & 336 & 72,41 & 128 \\
\hline 19 & Krayan Barat & 871 & 600 & 68,89 & 271 \\
\hline \multicolumn{6}{|c|}{ Jumlah } \\
\hline & & 62.490 & 43.912 & 70,27 & 18.578 \\
\hline
\end{tabular}

Sumber: Diskuncapil Kabupaten Nunukan Jumlah Penduduk DKB Semester 2 Tahun 2016

\begin{tabular}{|c|c|c|c|c|c|}
\hline \multirow[t]{2}{*}{ No } & \multirow[t]{2}{*}{ Kecamatan } & \multicolumn{4}{|c|}{ Anak 0-18 TAHUN } \\
\hline & & Jumlah Anak & Memiliki & $\%$ & Tidak Memiliki \\
\hline 1 & Sebatik & 2.318 & 2.060 & 88,87 & 258 \\
\hline 2 & Nunukan & 20.248 & 17.930 & 88,55 & 2.318 \\
\hline 3 & Sembakung & 2.146 & 1.585 & 73,86 & 561 \\
\hline 4 & Lumbis & 2.370 & 1.394 & 58,82 & 976 \\
\hline 5 & Krayan & 1.052 & 849 & 80,70 & 203 \\
\hline 6 & Sebuku & 3.312 & 1.822 & 55,01 & 1.490 \\
\hline 7 & Krayan Selatan & 472 & 461 & 97,67 & 11 \\
\hline 8 & Sebatik Barat & 3.536 & 2.906 & 82,18 & 630 \\
\hline 9 & $\begin{array}{l}\text { Nunukan } \\
\text { Selatan }\end{array}$ & 6.482 & 5.659 & 87,30 & 823 \\
\hline 10 & Sebatik Timur & 4.561 & 4.197 & 92,02 & 364 \\
\hline 11 & Sebatik Utara & 2.643 & 2.357 & 89,19 & 286 \\
\hline 12 & Sebatik Tengah & 2.604 & 1.174 & 83,49 & 430 \\
\hline 13 & Sei Menggaris & 3.291 & 1.364 & 71,83 & 927 \\
\hline 14 & Tulin Onsoi & 2.905 & 1.906 & 65,61 & 999 \\
\hline 15 & Lumbis Ogong & 2.159 & 1.670 & 77,35 & 489 \\
\hline 16 & $\begin{array}{l}\text { Sembakung } \\
\text { Atulai }\end{array}$ & 990 & 476 & 48,08 & 514 \\
\hline 17 & Krayan Tengah & 382 & 341 & 89,27 & 41 \\
\hline 18 & Krayan Timur & 437 & 350 & 80,09 & 87 \\
\hline 19 & Krayan Barat & 840 & 689 & 82,02 & 151 \\
\hline Jum & & 62.748 & 51.190 & 81,58 & 11.558 \\
\hline
\end{tabular}

Sumber : Diskuncapil Kabupaten Nunukan Jumlah Penduduk DKB Semester 2 Tahun 2017 


\begin{tabular}{|c|c|c|c|c|c|}
\hline \multirow[t]{2}{*}{ No } & \multirow[t]{2}{*}{ Kecamatan } & \multicolumn{4}{|c|}{ Anak 0-18 TAHUN } \\
\hline & & Jumlah Anak & Memiliki & $\%$ & $\begin{array}{c}\text { Tidak } \\
\text { Memiliki }\end{array}$ \\
\hline \multirow[t]{2}{*}{1} & Sebatik & 2318 & & 88,22 & \\
\hline & & & 2045 & & 273 \\
\hline \multirow[t]{2}{*}{2} & Nunukan & 20248 & & 90,44 & \\
\hline & & & 18313 & & 1935 \\
\hline \multirow[t]{2}{*}{3} & Sembakung & 2146 & & 77,54 & \\
\hline & & & 1664 & & 482 \\
\hline \multirow[t]{2}{*}{4} & Lumbis & 2370 & & 60,21 & \\
\hline & & & 1427 & & 943 \\
\hline \multirow[t]{2}{*}{5} & Krayan & 1052 & & 80,61 & \\
\hline & & & 848 & & 204 \\
\hline \multirow[t]{2}{*}{6} & Sebuku & 3312 & & 61,62 & \\
\hline & & & 2041 & & 1271 \\
\hline \multirow[t]{2}{*}{7} & Krayan & 472 & & 94,70 & \\
\hline & Selatan & & 447 & & 25 \\
\hline \multirow[t]{2}{*}{8} & Sebatik Barat & 3536 & & 86,93 & \\
\hline & & & 3074 & & 462 \\
\hline \multirow[t]{2}{*}{9} & Nunukan & 6482 & & 90,25 & \\
\hline & Selatan & & 5850 & & 632 \\
\hline 10 & Sebatik Timur & 4561 & & 96,29 & \\
\hline \multirow{2}{*}{11} & & & & 8060 & \\
\hline & Sebatik Utara & 2643 & 2368 & 89,60 & 275 \\
\hline \multirow[t]{2}{*}{12} & Sebatik & 2604 & & 84,68 & \\
\hline & Tengah & & 2205 & & 399 \\
\hline \multirow[t]{2}{*}{13} & Sei Menggaris & 3291 & & 73,23 & \\
\hline & & & 2410 & & 881 \\
\hline 14 & Tulin Onsoi & 2905 & 2007 & 69,09 & 898 \\
\hline \multirow[t]{2}{*}{15} & Lumbis & 2159 & & 77,54 & \\
\hline & Ogong & & 1674 & & 485 \\
\hline \multirow[t]{2}{*}{16} & Sembakung & 990 & & 53,84 & \\
\hline & Atulai & & 533 & & 457 \\
\hline \multirow[t]{2}{*}{17} & Krayan & 382 & & 86,91 & \\
\hline & Tengah & & 332 & & 50 \\
\hline 18 & Krayan Timur & 437 & 344 & 78,72 & 93 \\
\hline 19 & Krayan Barat & 840 & 674 & 80,24 & 166 \\
\hline \multicolumn{2}{|l|}{ Jumlah } & 62748 & 52648 & 83,90 & 10.100 \\
\hline
\end{tabular}

Sumber : Diskuncapil Kabupaten Nunukan Jumlah Penduduk DKB Juni Tahun 2018

Berdasarkan uraian data di atas menunjukkan bahwa pemenuhan hak anak atas dokumen kependudukan berupa akta kelahiran di kabupaten Nunukan dalam kurun waktu 2016-2018 telah terlaksana/dipenuhi oleh pemerintah daerah dalam hal ini Dinas Kependudkan Dan Pencatatan Sipil.
Tabel.1.6

Kepemilikan Akta Kelahiran Kecamatan Nunukan Tahun 2018

\begin{tabular}{llcccc}
\hline No & & \multicolumn{5}{c}{ Anak 0-18 TAHUN } \\
\hline & Kelurahan & Jumlah Anak & Memiliki & $\%$ & $\begin{array}{c}\text { Tidak } \\
\text { Memiliki }\end{array}$ \\
\hline 1 & $\begin{array}{l}\text { Nunukan } \\
\text { Timur }\end{array}$ & 5.803 & 5619 & 96.83 & 184 \\
\hline 2 & $\begin{array}{l}\text { Nunukan } \\
\text { Barat }\end{array}$ & 5.449 & 5129 & 94.13 & 320 \\
\hline 3 & $\begin{array}{l}\text { Nunukan } \\
\text { Utara }\end{array}$ & 2.644 & 2476 & 92.94 & 188 \\
\hline 4 & $\begin{array}{l}\text { Nunukan } \\
\text { Tengah }\end{array}$ & 4.748 & 4742 & 99.87 & 6 \\
\hline 5 & Binusan & 1.584 & 1440 & 90.91 & 144 \\
\hline & Jumlah & 20.248 & 19.406 & 95.84 & 842 \\
\hline
\end{tabular}

Sumber : Diskuncapil Kabupaten Nunukan Jumlah Penduduk DKB Mei Tahun 2018

Berdasarkan uraian data di atas menunjukkan bahwa pemenuhan hak anak atas dokumen kependudukan berupa Akta kelahiran khususnya di Kecamatan Nunukan telah terealisasi dari 4.403 anak yang tidak memiliki Akta kelahiran pada tahun 2016 menjadi 2.318 anak yang belum memiliki Akta kelahiran pada tahun 2017 atau sekitar 51\% hak anak atas dokumen Akta kelahiran telah terpenuhi dan tersisa 842 anak pada Mei 2018.

c) Faktor-Faktor Penyebab Tidak Terpenuhinya Hak Anak Atas Dokumen Akta Kelahiran

Anak sebagai penerus bangsa merupakan asset yang berharga untuk melanjutkan pembangunan, dimana anak sebagai subyek hukum mempunyai hak dan kewajiban yang dilindungi oleh hukum,dalam UndangUndang Nomor 23 Tahun 2002 tentang Perlindungan Anak, Pasal 21 menerangkan bahwa: ${ }^{8}$

"Negara dan pemerintah berkewajiban dan bertanggung jawab menghormati dan menjamin hak asasi setiap anak tanpa membedakan suku, agama, ras, golongan, jenis kelamin, etnik, budaya dan bahasa, status hukum anak, urutan kelahiran anak,

${ }^{8}$ Undang-Undang Nomor 23 Tahun 2002 Tentang Perlindungan Anak, Pasal 21. 
dan kondisi fisik dan/atau mental".

Pemberian jaminan terhadap status hukum anak (anak sah), salah satunya adalah dengan kepemilikan Akta kelahiran. Menurut Undang-undang Nomor 23 Tahun 2002 tentang Perlindungan Anak, Pasal 27 menerangkan bahwa: ${ }^{9}$

1. Identitas diri setiap anak harus diberikan sejak kelahirannya.

2. Identitas sebagaimana dimaksud dalamayat (1) dituangkan dalam Akta kelahiran.

3. Pembuatan Akta kelahiran didasarkan pada surat keterangan dari orang yang menyaksikan dan/atau membantu proses kelahiran.

4. Dalam hal anak yang proses kelahirannya tidak diketahui, dan orang tuanya tidak diketahui keberadaannya, pembuatan Akta kelahiran untuk anak tersebut didasarkan pada keterangan orang yang menemukannya.

Ketentuan pasal 27 Undang-undang Nomor 23 Tahun 2002 tentang Perlindungan Anak sesuai dengan Undang-undang Nomor 23 Tahun 2006 tentang Administarsi Kependudukan, Pasal 27 yang menyebutkan bahwa: ${ }^{10}$

1. Setiap kelahiran wajib dilaporkan oleh Penduduk kepada Instansi Pelaksana di tempatterjadinyaperistiwakelahiran paling lambat60(enam puluh)hari sejak kelahiran.

2. Berdasarkan laporan sebagaimana dimaksud pada ayat (1), Pejabat Pencatatan SipilmencatatpadaRegisterAktaKelahiran dan menerbitkan Kutipan Akta Kelahiran.

Kepemilikan Akta kelahiran menjadi sangatlah penting bagi anak karena dengan adanya Akta kelahiran tersebut, seorang anak memiliki bukti secara hukum tentang statusnya sebagai anak sah dimata hukum, sebagai bukti ahli waris yang sah serta memperoleh kedudukan yang pasti sebagai Warga Negara Indonesia. Dalam kenyataan yang ada di tengah masyarakat, pentingnya kepemilikan Akta kelahiran belum diketahui

\footnotetext{
${ }^{9}$ Undang-Undang Nomor 23 Tahun 2002 Tentang Perlindungan Anak, Pasal 27

${ }^{10}$ Undang-undang Nomor 23 Tahun 2006 tentang Administarsi Kependudukan, Pasal 27
}

dan disadari oleh masyarakat luas. Banyak faktor menyebabkan keterlambatan dalam kepemilikan Akta kelahiran bagi anak. Faktor- faktor tersebut antara lain sebagai berikut :11

\section{Rendahnya Kesadaran Masyarakat}

Banyaknya masyarakat yang sibuk dengan pekerjaannya sering kali mengakibatkan merekamenjadikurangpahamakanpentingnya suatu Akta kelahiran sehingga menjadikan keterlambatan dalam mendaftarkan suatu peristiwa kelahiran dan mengakibatkan keterlambatan dalam kepemilikan Akta kelahiran. Masyarakat belum menganggap penting kepemilika Akta kelahiran bagi anak sejak dini,sebagian besar masyarakat membuat Akta kelahiran menjelang anak masuk sekolah atau ketika ada kebutuhan mendesak seperti pemberian bantuan beasiswa oleh pemerintah,pembuatan Kartu BPJS . Rendahnya kesadaran masyarakat ini juga di sebabkan taraf pendidikan masyarakat yang masih rendah serta banyak penduduk yang berpindah - pindah tempat tinggal. Rendahnya kesadaran masyarakat juga dalam bentuk : ${ }^{12}$

1. Ketidaktahuan masyarakat tentang kewajibannya untuk segera mendaftarkan peristiwa kelahiran di Kantor Dinas Kependudukan dan Pencatatan Sipil setempat.

2. Kurangnya kesadaran masyarakat akan pentingnya Akta kelahiran sebagai jaminan hukum bagi anak, dimasa yang akan datang.

3. Pandangan masyarakat yang keliru mengenai proses kepemilikan Akta kelahiran anak di Kantor Dinas Kependudukan dan Pencatatan Sipil yang membutuhkan waktu yang lama.

4. Kurangnya sosialisasi yang dilakukan oleh pemerintah daerah setempat kepada masyarakattentangpentingnyakepemilikan Akta kelahiran.

\section{Ketersedian Pegawai Yang Terbatas}

\footnotetext{
${ }^{11}$ Wawancara dengan Kepala Dinas Kependudukan Dan Pencatatan Sipil Kabupaten Nunukan

${ }^{12}$ Dayu Widarini.(2007). Karya Ilmiah Tugas Akhir, UNS, hlm.2
} 
Dalam pelaksanaan administrasi kependudukan kegiatan administrasi kependudukan di bagi berdasarkan kewenangan. Undang-Undang Nomor 23 Tahun 2006 tentang Administrasi Kependudukan membagi kewenangan penyelenggaraan pembuatan Akta kelahiran secara berjenjang sebagai berikut :

a. Pemerintah berkewajiban dan bertanggung jawab menyelenggarakan administrasi kependudukan secara nasional yang dilakukanolehMenteridengankewenangan meliputi :

1. koordinasi antar instansi dalam urusan administrasi kependudukan;

2. penetapan sistem, pedoman, dan standar pelaksanaan administrasi kependudukan;

3. sosialisasi administrasi kependudukan;

4. pemberian bimbingan, supervisi, dan konsultasi pelaksanaan urusan administrasi kependudukan;

5. pengelolaan dan penyajian Data Kependudukan berskala nasional dan;

6. pencetakan, penerbitan, dan distribusi blangko dokumen kependudukan.

b. Pemerintah Provinsi berkewajiban dan bertanggung jawab menyelenggarakan urusan administrasi kependudukan, yang dilakukan oleh gubernur dengan kewenangan meliputi :

\section{1. koordinasi penyelenggaraan} administrasi kependudukan;

2. pemberian bimbingan, supervisi, dan konsultasi pelaksanaan

3. pendaftaran penduduk dan pencatatan sipil;

4. pembinaan dan sosialisasi penyelenggaraan administrasi kependudukan;

5. pengelolaan dan penyajian data kependudukan berskala PROVINSIdan;

6. koordinasi pengawasan atas penyelenggaraan administrasi kependudukan.

c. Pemerintah kabupaten/kota berkewajiban dan bertanggung jawab menyelenggarakan urusan administrasi kependudukan, yang dilakukan oleh bupati/walikota dengan kewenangan meliputi :

1. koordinasi penyelenggaraan administrasi kependudukan;

2. pembentukan Instansi Pelaksana yang tugas dan fungsinya di bidangadministrasi kependudukan;

3. pengaturan teknis penyelenggaraan administrasi kependudukan sesuai dengan ketentuan Peraturan Perundangundangan;

4. pembinaan dan sosialisasi penyelenggaraan administrasi kependudukan; pelaksanaan kegiatan pelayanan masyarakat di bidang administrasi kependudukan;

5. penugasan kepada desa untuk menyelenggarakan sebagian urusan administrasi kependudukan berdasarkan asas tugas pembantuan;

6. pengelolaan dan penyajian data kependudukan berskala kabupaten/kota dan;

7. koordinasi pengawasan atas penyelenggaraan Administrasi Kependudukan.

d. Instansi Pelaksana melaksanakan urusan administrasi kependudukan dengan kewajiban yang meliputi :

1. mendaftar peristiwa kependudukan dan mencatat peristiwa penting;

2. memberikan pelayanan yang sama dan profesional kepada setiap penduduk atas pelaporan peristiwa kependudukan dan peristiwa penting;

3. menerbitkan dokumen kependudukan;

4. mendokumentasikan hasil pendaftaran penduduk dan pencatatan sipil;

5. menjamin kerahasiaan dan keamanan data atas peristiwa pependudukan dan peristiwa penting; dan

6. melakukan verifikasi dan validasi data dan informasi yang disampaikan oleh penduduk dalam pelayanan pendaftaran penduduk dan pencatatan sipil.

Mengacu kewenangan administrasi kependudukan Diskuncapil masuk kategori instansi pelaksana admninistrasi 
kependudukan. Untuk bersama kita ketahui bahwa tugas Diskuncapil tidak semata-mata mengurus pembuatan Akta kelahiran namun ada juga tugas lain seperti pelayanan pembutan Kartu Tanda Penduduk,Kartu Keluarga,Akta Pernikahan,Akta Kematian,Penyusunan Daptar Pokok Pemilih,Pengolahan Data Kependudukan dan tugas - tugas lainnya sehingga sumber daya manusia yang ada di bagi secara proporsional agar semua tugas yang menjadi kewajiban diskuncapil dapat berjalan sebagaimana mestinya. Adapun jumlah pegawai Dinas Kependudukan dan Pencatatan Sipil yang membidangi pembuatan Akta kelahiran sebanyak orang terdiri dari 1 Kasi dan pegawai teknis.

\section{Kepadatan Penduduk Kecamatan Nunu- kan}

Berdasarkan data anak usia 0-18 Tahun dari 19 Kecamatan yang ada di Kabupaten Nunukan,Kecamatan Nunukan menduduki posisi palang banyak anak yang tidak memiliki Akta kelahiran sebesar 4403 anak pada tahun 2016 dan 2318 anak pada tahun 2017 anak hal ini di sebabkan sebagian besar penduduk kabupaten Nunukan tinggal/ berdomisili di Kecamatan Nunukan yang menyebabkan,keluar masuknya penduduk tanpa dokumen kependudukan sangat tinggi.

\section{Kondisi Geografis Kabupaten Nunukan}

Secara geografis Kabupaten Nunukan memiliki 17 Kecamatan,dalam pelaksanaan pemenuhan dokumen kependudukan berupa Akta kelahiran Dinas Kependudukan dan Pencatatan Sipil membagi wilayah pelayanan menjadi 3 (Tiga) Zonasi yaitu :

1. Zona satu (zona merah) zona ini meliputi Enam (6) Kecamatan yaitu Krayan Tengah,Krayan Timur,Krayan Barat,Krayan Selatan,Krayan dan Lumbis Ogong. Zona ini menjadi prioritas pemerintah untuk pelayanan pembuatan Akta kelahiran karena jarah tempuh warga jika mengurus langsung ke Kantor Dinas Kependudukan dan Pencatatan Sipil sangat jauh dan membutuhkan biaya yang besar sehingga pemerintah langsung memberikan pelayananlangsungke daerahbersangkutan di Kantor Kecamatan setempat.

2. Zona dua (zona kuning) zona ini meliputi Enam (6) Kecamatan yaitu S e mbakung, Lumbis, S ebuku, Sei Menggaris, Tulin Onsoi dan Sembakung Atulai. Zona ini menjadi zona kedua yang mendapatkan prioritas pelayanan pembuatan Akta kelahiran dengan sistem datang langsung mengurus ke Dinas Kependudukan dan Pencatatan Sipil atau melalui layanan Akta keliling.

3. Zona tiga (zona hijau) zona ini meliputi tujuh (7) Kecamatan yaitu Sebatik,Nunukan,Sebatik Barat,Nunukan Selatan,Sebatik Timur,Sebatik Tengah dan Sebatik Utara,). Zona ini menjadi zona dimana masyarakat di harapkan secara aktif untuk melakukan pengurusan pembuatan akya kelahiran secara langsung ke kantor Dinas Kependudukan dan Pencatatan Sipil.

\section{d) Akibat Hukum Anak Yang Tidak Memi- liki Akta Kelahiran}

Akta kelahiran sebagai salah satu hal paling penting yang harus dipikirkan oleh orang tua setelah kelahiran anak. Persoalan pembuatan akta kelahiran menjadi hal yang sering terlupakan untuk di tunaikan oleh orang tua. Padahal selaku warga negara, kelahiran seorang anak haruslah tercatat sesuai dengan ketentuan hukum yang berlaku. Pencatatan ini dilakukan dengan prosedural tertentu dan diarsipkan dalam lembaran yang dikenal dengan nama Akta Kelahiran. Akta kelahiran ini merupakan awal dari pencatatan terhadap diri seseorang di mata hukum di Indonesia.

Dalam Pasal 27 (1) Undang-undang No. 23 tahun 2006 tentang Administrasi Kependudukan disebutkan bahwa setiap kelahiran wajib dilaporkan oleh penduduk kepada instansi pelaksana di tempat terjadinya peristiwa kelahiran paling lambat 60 (enam puluh) hari sejak kelahiran. Selanjutnya, Pasal 27 (2) menyebutkan bahwa berdasarkan laporan sebagaimana dimaksud pada ayat (1), Pejabat Pencatatan Sipil mencatat pada Register Akta Kelahiran dan menerbitkan 
Kutipan Akta Kelahiran. Berdasarkan undang-undang tersebut, para orang tua wajib segera membuat Akta kelahiran bagi anak mereka.

Hak identitas bagi seorang anak dinyatakan tegas dalam pasal 5 Undang - Undang Nomor 23 Tahun 2002 tentang Perlindungan Anak. Pasal tersebut menyebutkan bahwa "Setiap anak berhak atas suatu nama sebagai identitas diri dan status kewarganegaraan”. Masalah identitas bagi anak juga ditegaskan pada pasal 27 ayat (1) dan (2) yang menyatakan, ayat (1) "Identitas diri setiap anak harus diberikan sejak kelahirannya", dan ayat (2) berbunyi "identitas sebagaimana dimaksud ayat (1) dituangkan dalam akte kelahiran". Sementara itu Undang - Undang Dasar 1945 Pasal 28 D ayat (1) menyatakan bahwa"setiap orang berhak atas pengakuan, jaminan, perlindungan, dan kepastian hukum yang adil serta perlakuan yang sama di hadapan hukum". Selain itu Undang - Undang Dasar 1945 juga memberikan jaminan atas status kewarganegaraan sebagaimana diatur dalam 28 D ayat (4) yang menyatakan, "setiap orang berhak atas status kewarganegaraan".

Akta kelahiran adalah bentuk identitas setiap anak yang menjadi bagian tidak terpisahkan dari hak sipil dan politik warga negara. Hak atas identitas merupakan bentuk pengakuan negara terhadap keberadaan seseorang di depan hukum. Ketidakpunyaan Akta kelahiran dapat menimbulkan akibat hukum bagi anak antara lain :

1. Anak tidak mendapatkan pemenuhan hakhakasasinyasecarapenuholehnegaraseperti kesehatan,pendidikan maupun jaminan sosial lainnya.

2. Dalam penanganan perkara Anak yang berhadapan dengan Hukum (ABH), anak jugakerap dirugikan dankehilangan haknya karena penentuan usia di proses peradilan berdasarkan akte kelahiran.

3. Ketiadaan kepemilikan Akta kelahiran ini, menyebabkanketidakjelasanidentitasanak, yang akan membawa sejumlah implikasi seperti diskriminasi,rawan menjadi korban perdagangan manusia, mudah dijadikan pekerja anak, rawan menjadi korban kejahatan seksual, dan lain-lain.

Perlindungan hak atas identitas anak di atur dalam beberapa peraturan antara lain sebagai berikut :

Pasal 28B ayat (2) Undang - Undang Dasar Negara Republik Indonesia 1945

"Setiap anak berhak atas kelangsungan hidup, tumbuh, dan berkembang serta berhak atas perlindungan dari kekerasan dan diskriminasi"

Pasal 28D ayat (1) Undang - Undang Dasar Negara Republik Indonesia 1945

"Setiap orang berhak atas pengakuan, jaminan, perlindungan, dan kepastian hukum yang adil serta perlakuan yang sama di hadapan hokum"

Pasal 28H ayat (2) Undang - Undang Dasar Negara Republik Indonesia 1945

"Setiap orang berhak mendapat kemudahan dan perlakuan khusus untuk memperoleh kesempatan dan manfaat yang sama guna mencapai persamaan dan keadilan" Pasal 28I ayat (1) Undang - Undang Dasar Negara Republik Indonesia 1945

"Hak untuk hidup, hak untuk tidak disiksa, hak kemerdekaan pikiran dan hati nurani, hak beragama, hak untuk tidak diperbudak, hak untuk diakui sebagai pribadi di hadapan hukum, dan hak untuk tidak dituntut atas dasar hukum yang berlaku surut adalah hak asasi manusia yang tidak dapat dikurangi dalam keadaan apa pun."

Pasal 28I ayat (2) Undang - Undang Dasar Negara Republik Indonesia 1945

Setiap orang berhak bebas dari perlakuan yang bersifat diskriminatif atas dasar apa pun dan berhak mendapatkan perlindungan terhadap perlakuan yang bersifat diskriminatif itu.

Selain di atur dalam Undang Undang Dasar 1945 hak anak atas identitas di atur dalam Undang - Undang Nomor 39 Tahun 1999 tentang Hak Asasi Manusia:

\section{Pasal 5}

1. Setiap orang diakui sebagai manusia pribadi yang berhak menuntut dan memperoleh 
perlakuan serta perlindungan yang sama sesuai dengan martabat kemanusiaannya di depan hukum.

2. Setiap orang berhak mendapat bantuan dan perlindunganyang adildaripengadilanyang obyektif dan tidak berpihak.

3. Setiap orang yang termasuk kelompok masyarakatyangrentanberhakmemperoleh perlakuandanperlindunganlebihberkenaan dengan kekhususannya.

\section{Pasal 52}

1. Setiap anak berhak atas perlindungan oleh orangtua, keluarga, masyarakat, dannegara.

2. Hak anak adalah hak asasi manusia dan untuk kepentingannya hak anak itu diakui dan dilindungi oleh hukum bahkan sejak dalam kandungan.

\section{Pasal 53}

1. Setiap anak sejak dalam kandungan, berhak untuk hidup, mempertahankan hidup, dan meningkatkan taraf kehidupannya.

2. Setiap anak sejak kelahirannya, berhak atas suatunamadanstatuskewarganegaraannya. Hak atas identitas anak juga di atur dalam Undang - Undang Nomor 23 Tahun 2002 tentang Perlindungan Anak sebagai berikut :

\section{Pasal 3}

Perlindungan anak bertujuan untuk menjamin terpenuhinya hak-hak anak agar dapat hidup, tumbuh, berkembang, dan berpartisipasi secara optimal sesuai dengan harkat dan martabat kemanusiaan, serta mendapat perlindungan dari kekerasan dan diskriminasi, demi terwujudnya anak Indonesia yang berkualitas, berakhlak mulia, dan sejahtera.

\section{Pasal 4}

Setiap anak berhak untuk dapat hidup, tumbuh, berkembang, dan berpartisipasi secara wajar sesuai dengan harkat dan martabat kemanusiaan, serta mendapat perlindungan dari kekerasan dan diskriminasi.

\section{Pasal 5}

Setiap anak berhak atas suatu nama sebagai identitas diri dan status kewarganegaraan.

\section{Pasal 27}

1. Identitas diri setiap anak harus diberikan sejak kelahirannya.
2. Identitas sebagaimanadimaksud dalamayat (1) dituangkan dalam Akta kelahiran.

3. Pembuatan Akta kelahiran didasarkan pada surat keterangan dari orang yang menyaksikan dan/atau membantu proses kelahiran.

\section{Pasal 28}

1. Pembuatan Akta kelahiran menjadi tanggung jawab pemerintah yang dalam pelaksanaannya diselenggarakan serendahrendahnya pada tingkat kelurahan/desa.

2. Pembuatan Akta kelahiran sebagaimana dimaksud dalam ayat (1) harus diberikan paling lambat 30 (tiga puluh) hari terhitung sejak tanggal diajukannya permohonan.

3. Pembuatan Akta kelahiran sebagaimana dimaksuddalamayat(1)tidakdikenaibiaya. Hak atas identitas anak juga di atur dalam Undang - Undang Nomor 12 Tahun 2005 tentang Ratifikasi Kovenan Internasional Hak-Hak Sipil dan Politik antara lain :

\section{Pasal 24}

1. Setiap anak, tanpa diskriminasi yang berkenaan dengan ras, warna kulit, jenis kelamin, bahasa, agama, asal-usul kebangsaan atau sosial, harta benda atau kelahiran, berhak atas upaya-upaya perlindungansebagaimanayangdibutuhkan oleh statusnya sebagai anak di bawah umur, oleh keluarga, masyarakat dan Negara.

2. Setiap anak harus didaftarkan segera setelah lahir dan harus mempunyai nama.

3. Setiap anak berhak memperoleh kewarganegaraan.

Hak atas identitas anak juga di atur dalam

Konvensi PBB tentang Hak Anak (United Nation's Convention on The Rights of The Child) antara lain :

\section{Pasal 7}

1. Anak harus didaftarkan segera setelah kelahirannya, dansejakkelahirannyaberhak untuk memperoleh sebuah nama, untuk memperoleh kewarganegaraan, dan, sebisa mungkin, untuk mengetahui orang tuanya dan dibesarkan oleh orang tuanya.

2. Negara-negara Pihak harus menjamin penerapanhak-hakini,sesuaidenganhukum 
nasional dan kewajiban mereka menurut instrumen internasional yang relevan dalam bidang ini, khususnya apabila anak menjadi tanpa kewarganegaraan.

\section{Pasal 8}

Negara Pihak berjanji untuk menghormati hak anak untuk mempertahankan identitasnya, termasuk kewarganegaraan, nama dan hubungan kekeluargaannya sebagaimana diakui oleh hukum tanpa campur tangan yang tidak sah.

Hak atas identitas anak juga di atur dalam Undang - Undang Nomor 23 Tahun 2006 tentang Administrasi Kependudukan antara lain :

\section{Pasal 2}

Setiap Penduduk mempunyai hak untuk memperoleh:

a. Dokumen Kependudukan;

b. pelayanan yang sama dalam Pendaftaran

Penduduk dan Pencatatan Sipil;

c. perlindungan atas Data Pribadi;

d. kepastian hukum atas kepemilikan dokumen;

e. informasi mengenai data hasil Pendaftaran Penduduk dan

f. Pencatatan Sipil atas dirinya dan/atau keluarganya; dan ganti rugi dan pemulihan nama baik sebagaiakibatkesalahan dalamPendaftaran Penduduk dan Pencatatan Sipil serta penyalahgunaan Data Pribadi oleh Instansi Pelaksana.

\section{KESIMPULAN}

1. Kebijakan pemerintah daerah Kabupaten Nunukan dalam memenuhi hak anak atas akta kelahiran telah terlaksana sesuai dengan ketentuan peraturan perundangperundangan yakni dengan melakukan kerjasama dengan opd terkait serta pelayanan langsung ke masyarakat.

2. Faktor utama yang menyebabkan tidak terpenuhinya hak anak atas akta kelahiran adalah rendahnya kesadaran masyarakat untuk mengurus pembuatan akta kelahiran dan keteresediaan sdm diskuncapil sebagai leading sektor yang masih terbatas.
3. Akibathukumbagianakyangtidakmemiliki akta kelahiran adalah tidak terpenuhinya hak-hak anak oleh negara.

\section{DAFTAR PUSTAKA}

Abdul Latif,.(2005). Hukum dan United Nation, Buku Pedoman Tentang Sistem Pencatatan Sipil dan Sistem Vital Statistik Kebijakan dan Protokol Pengeluaran Catatan Pribadi dan Pencatatanya Dalam Arsip, Jakarta: PT. Citra Grafika Pratama, hlm.6.

Gouw Giok Siong.(2004).Pengertian Tentang Negara Hukum, Jakarta: Keng Po, 1955, hlm.12-13.

Muin Fahmal.(2006).Peran Asas-Asas Umum Pemerintahan yang layak dalam MewujudkanPemerintahan yang Bersih, Cetakan I, Yogyakarta: UII Press, hlm. 94

Rochmat Soemitro.(1976).Peradilan Administrasi Dalam Hukum Pajak Di Indonesia,Cetakan ke-IV, Jakarta - Bandung: PT. Eresco, hlm. 18.

Salim HS.(2001). Pengantar Hukum Perdata Tertulis $(B W)$, Bandung, hlm.24.

Soehino.(1998). Ilmu Negara,Cetakan III, Yogyakarta: Liberty, hlm. 50-51.

Sudikno Mertokusumo.(1982). Hukum Acara Perdata Indonesia, Yogyakarta: Liberty, hlm.142.

Utrecht.(2005). Pengantar Hukum Administrasi Peraturan

Kebijaksanaan ( Beleidsregel) pada Pemerinthan Daerah,Cetakan I, Yogyakarta: UII Press, hlm.15.

Utrercht.(1963). Pengantar Administrasi Negara Indonesia, Jakarta: PT. Ichtiar, hlm.310.

Peraturan Perundang-Undangan:

Undang Undang N. 26 Tahun 2000 tentang Pengadilan HAM 
Undang Undang No. 11 Tahun 2006 tentang Ratifikasi Konvensi HAM ekosob

Undang Undang No.39 Tahun 1999 tentang HAM

Undang-Undang Dasar 1945.

Undang-Undang Nomor 12 Tahun 2006 Tentang Kewarganegaraan

Undang-undang Nomor 23 Tahun 2002 jo. Undang-undang Nomor 35 Tahun 2014 tentang Perlindungan Anak

Undang-Undang Nomor 24 Tahun 2013 tentang Perubahan Atas Undang-Undang Nomor 23 Tahun 2006 tentang Administrasi Kependudukan.

Universal Declaration of Human Rights 1948 (Deklarasi Umum tentang HAM)

Keputusan Presiden Nomor 36 Tahun 1990 tentang Pengesahan Convention Of The Right Of TheChild (Konvensi tentang Hak $\square$ Hak Anak)

Permendagri Nomor 9 tahun2016 Tentang Percepatan Peningkatan Cakupan Kepemilikan Akta Kelahiran http://irham1997.wordpress.com/2009/11/06/ Akta-kelahiran-hak-masyarakat-atas-identitas.

http://pedulihukum.blogspot.com http://www.landasanteori.com/2015/09/ pengertian-pencatatan-kelahiran-menurut 